\title{
Determination of Power Value Effect in Laser Welding Method on Strength of AISI 430 Ti Stainless Steel
}

\author{
${ }^{1}$ Koray Güler*, ${ }^{2}$ Ömer Faruk Erkendirci, ${ }^{3}$ Ahmet Avcı
}

${ }^{1}$ BSH Home Appliances Company 59501 Çerkezköy, Tekirdağ, TURKEY

${ }^{2}$ Istanbul Aydın University, Faculty of Engineering, Mechanical Engineering Department 34000, İstanbul, Turkey

${ }^{3}$ Necmettin Erbakan University, Faculty of Engineering, Biomedical Engineering Department 42000, Konya, Turkey

\begin{abstract}
A Laser is a device that means light amplification by stimulated emission of radiation, can be obtained in various ways, and strengthens electromagnetic heat. The usage area of titanium alloys has been limited to only special production vehicles in recent years due to their high costs. Today, one of the most advantageous metals for the automotive and aerospace industry due to the advances in production techniques and low weight and high resistance against corrosion. The Laser welding method is one of the most important joining techniques due to its fixed properties. Power values one of the most effective parameters for joint strength. In this study, the effect of the power factor on joint strength during the welding process of the AISI $430 \mathrm{Ti}$ stainless sheet was investigated. According to tensile test trials, observed that the rupture strength increases with the parameter of increased laser power but the value has been down after a certain point.
\end{abstract}

Keywords: Laser Welding, Titanium Alloy Metals, Tensile Test, Laser Welding Power, Laser Technology, Metal Joining.

\begin{tabular}{|clll|}
\hline Nomenclature & & \\
$P_{d}$ & power density & $A_{G}$ & tensile elongation \\
$P_{i n}$ & laser beam power & $R_{B}$ & rupture strength \\
$D_{b}$ & focus point diameter & $A_{80 \mathrm{~mm}}$ & elongation at rupture \\
$m_{E}$ & elasticity module & $L_{0}$ & measuring length \\
$R_{p 0.2}$ & value of $0.2 \%$ permanent elongation amount & $a_{0}$ & thickness \\
$R_{m}$ & tensile strength & $b_{0}$ & width \\
$F_{m}$ & maximum force & $S_{0}$ & breaking surface area of the sample \\
\hline
\end{tabular}

\section{Introduction}

Metal joining with the laser welding method is one of the production methods used in the sheet metal industry.[1](Fig. 1) According to other welding methods limited welding zone, precise adjustability, and capable of different types of metals special properties of laser welding technology.[2, 3, 4]

Titanium metal was discovered in 1791 by William Gregor. The specific gravity of the titanium material is $4.51 \mathrm{~g} / \mathrm{cm}^{3}$ and the melting temperature is $1680^{\circ} \mathrm{C}$.AISI $430 \mathrm{Ti}$ is one of the most common Titanium alloys. The steel stabilization is enhanced with Titanium. It contains X3CrTi17.

$[5,6,7]$ Titanium and its alloys can be used surgical splints, vascular stents, metal, automotive, and aerospace industry.[8] Titanium alloys have mostly usage areas with laser welding technology. It has strong resistance, high corrosive resistance, high-temperature resistance, easy soldering, and easy welding.[9, 10, 11] 


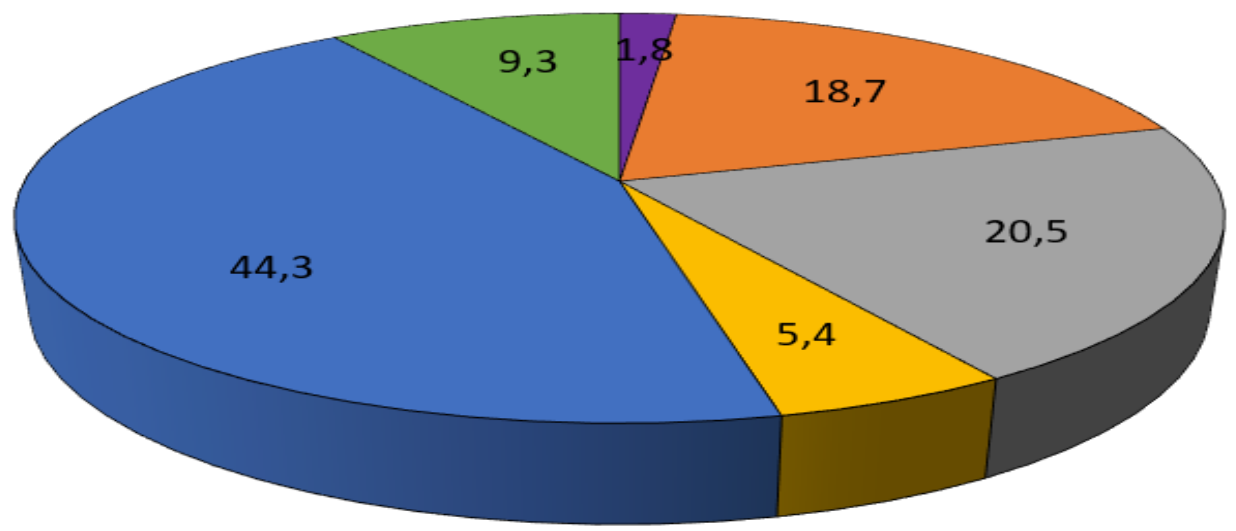

Drilling $\square$ Welding $\square$ Writing $\square$ Micro-electronic $\square$ Cutting $\square$ Others

Fig. 1: Distribution in the usage areas of lasers[12]

Laser power, welding speed, and focus point are the most important parameters for joint strength at laser welding. $[11,13]$ The parameters affect strength of the joint due to mostly penetration depth and melted area. Beneficial of this method, interface reaction is less than the others.[14, 15, 16]

In this study, as mentioned above, samples that have been prepared with two different laser welding powers were subjected to tensile tests. Investigations were made to define how metal joint strength is affected by laser power. Thus, the effects of laser power on joint strength were examined by comparing two different values; the data has been reported with experiments and investigations.

\section{Materials and Experiments}

In this study, AISI $430 \mathrm{Ti}$ ferritic Titanium alloy stainless steel that chemical composition is given in Table 1, is used. The sheet used has $0.6 \mathrm{~mm}$ thickness. The sheets are welded with TRUMPF LASER argon gas welding machine in different laser beam powers, without using additional metal.

Table 1: Chemical composition of AISI430 Ti alloy[17]

\begin{tabular}{|l|l|l|l|l|l|l|l|l|}
\hline $\begin{array}{l}\text { Chemica } \\
1 \\
\text { Element }\end{array}$ & $\begin{array}{l}\text { Carbon } \\
(\mathrm{C})\end{array}$ & $\begin{array}{l}\text { Chromiu } \\
\mathrm{m}(\mathrm{Cr})\end{array}$ & $\begin{array}{l}\text { Titanium } \\
(\mathrm{Ti})\end{array}$ & $\begin{array}{l}\text { Mangane } \\
\text { se (Mn) }\end{array}$ & $\begin{array}{l}\text { Phosphoro } \\
\text { us }(\mathrm{P})\end{array}$ & $\begin{array}{l}\text { Silicon } \\
(\mathrm{Si})\end{array}$ & $\begin{array}{l}\text { Sulfur } \\
(\mathrm{S})\end{array}$ & $\begin{array}{l}\text { Iron } \\
(\mathrm{Fe})\end{array}$ \\
\hline $\begin{array}{l}\text { Percenta } \\
\text { ge\% }\end{array}$ & $\begin{array}{l}0.0 \\
0.05\end{array}$ & $\begin{array}{l}16.00- \\
18.00\end{array}$ & $\begin{array}{l}0.50 \\
0.80\end{array}$ & $\begin{array}{l}0.0 \\
1.00\end{array}$ & $-0.0-0.04$ & $\begin{array}{l}0.0 \\
1.00\end{array}$ & $\begin{array}{l}0.0 \\
0.02\end{array}$ & $\begin{array}{l}80.0- \\
84.0\end{array}$ \\
\hline
\end{tabular}

Determination of mechanical properties of joints, welded tensile test samples were made according to DIN EN ISO 6892-1. Three samples have been were prepared for both conditions.

\section{Table 2: Parameters for study}

\begin{tabular}{|l|l|l|l|}
\hline $\begin{array}{l}\text { Laser Power } \\
\text { (Watt) }\end{array}$ & $\begin{array}{l}\text { Welding Speed } \\
(\mathrm{m} / \mathrm{min})\end{array}$ & $\begin{array}{l}\text { Shielding } \\
\text { Gas }\end{array}$ & $\begin{array}{l}\text { Focus Point Diameter } \\
(\mathrm{mm})\end{array}$ \\
\hline 1350 & 5 & Argon & 0,9 \\
\hline 1450 & 5 & Argon & 0,9 \\
\hline
\end{tabular}

The experimental study has been done with two laser power values to a determination of power value effect on joint strength. The used laser welding parameters were saved in Table 2. Samples have been cut as are given in Figure 2. 


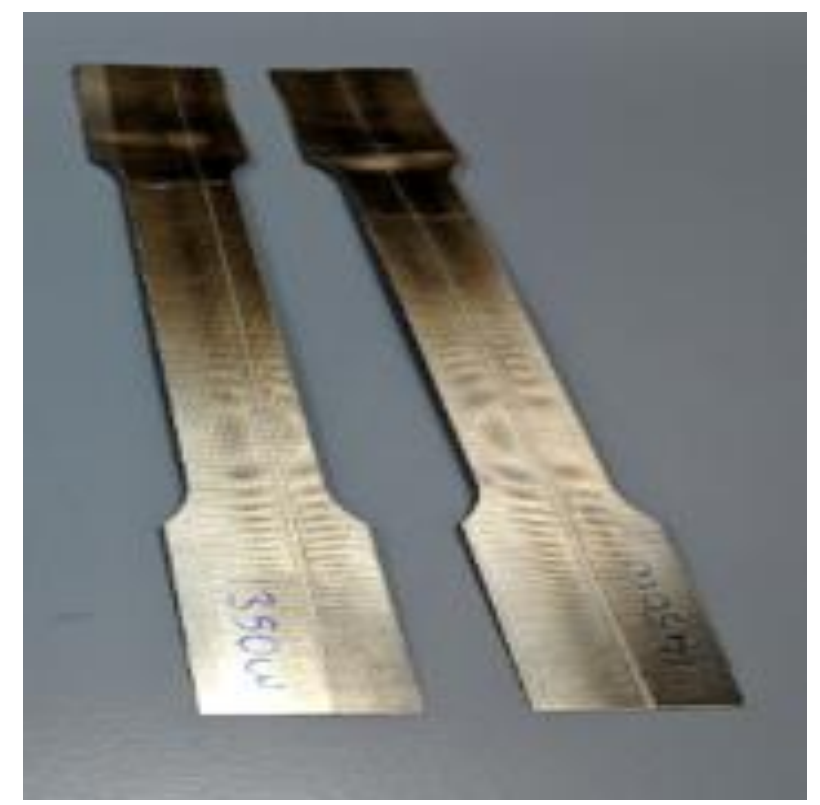

Fig. 2: Sample pieces for tensile test

Tensile tests were applied $90^{\circ}$ perpendicular on the machined samples to rolling direction accordance with DIN 50125 and DIN EN ISO 6892-1. Tensile tests were performed with ZWICK / ROELL 20kN tensile device. The mounted samples on the device have been shown in Figure 3.

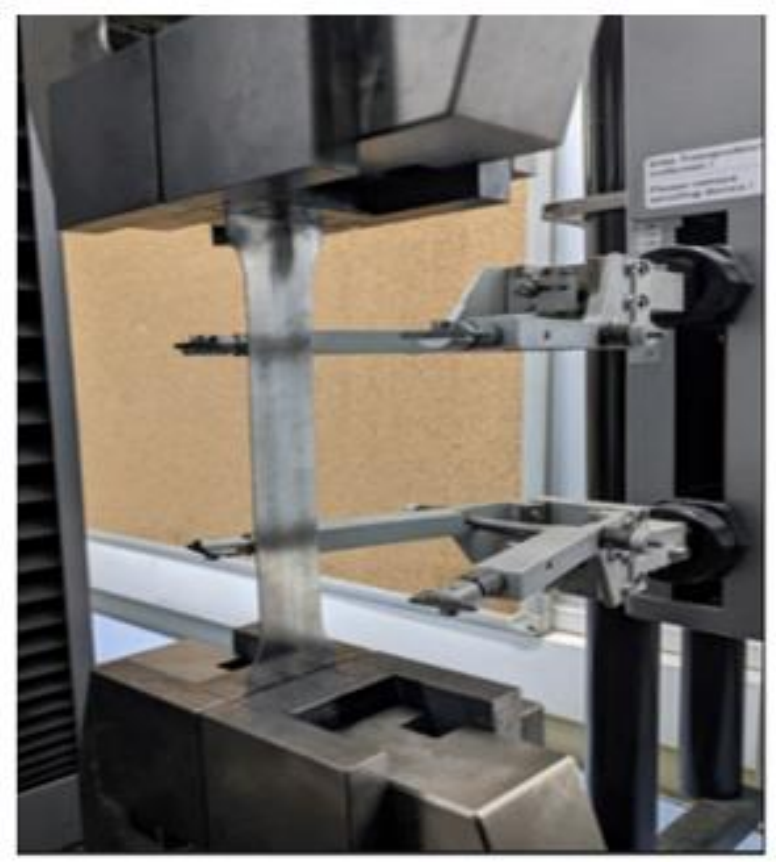

Fig. 3: Mounted samplebefore tensile test

\section{Results and discussion}

$\mathrm{R}_{\mathrm{p} 0.2}$ has been investigated between $1350 \mathrm{~W}$ and $1450 \mathrm{~W}$ and downward trend was seen. In a similar study Uyguntürk et al., produced titanium alloy samples which were with different laser welding powers, applied tensile tests and they reported that $R_{p}$ and $R_{B}$ values with laser power downward trend after a certain point.[14]

Similar behaviour was seen for $\mathrm{R}_{\mathrm{m}}$ at results. It was seen that the value decreasing with the increasing power parameter. It has been seen that when the material was welded by using higher power, it directly affects joint area its strength down after a certain value. In accordance to Akkurt et al., heat input rises up due to laser power increasing that causes negative effect Rm value.[18] Kökey et al. made similar researches, they verified positive relationship to a certain value between laser power and $\mathrm{Rm}$. [19] $\mathrm{R}_{\mathrm{B}}$ value was similar to the other strength values had a significant decrease in $1450 \mathrm{~W}$. 
Table 3: Tensile test results with different Laser welding powers

\begin{tabular}{|l|l|l|l|l|l|l|l|l|l|l|l|l|}
\hline $\begin{array}{l}\text { Power } \\
\text { W }\end{array}$ & $\begin{array}{l}\text { Sample } \\
\text { Number }\end{array}$ & $\begin{array}{l}\mathrm{m}_{\mathrm{E}} \\
\mathrm{GPa}\end{array}$ & $\begin{array}{l}\mathrm{R}_{\mathrm{p} 0.2} \\
\mathrm{MPa}\end{array}$ & $\begin{array}{l}\mathrm{R}_{\mathrm{m}} \\
\mathrm{MPa}\end{array}$ & $\begin{array}{l}\mathrm{F}_{\mathrm{m}} \\
\mathrm{kN}\end{array}$ & $\begin{array}{l}\mathrm{A}_{\mathrm{G}} \\
\%\end{array}$ & $\begin{array}{l}\mathrm{R}_{\mathrm{B}} \\
\mathrm{MPa}\end{array}$ & $\begin{array}{l}\mathrm{A}_{80 \mathrm{~mm}} \\
\%\end{array}$ & $\begin{array}{l}\mathrm{L}_{0} \\
\mathrm{~mm}\end{array}$ & $\begin{array}{l}\mathrm{a}_{0} \\
\mathrm{~mm}\end{array}$ & $\begin{array}{l}\mathrm{b}_{0} \\
\mathrm{~mm}\end{array}$ & $\begin{array}{l}\mathrm{S}_{0} \\
\mathrm{~mm}^{2}\end{array}$ \\
\hline 1350 & 1 & 170 & 402 & 489,5 & 5,7 & 12,8 & 386 & 25,3 & 80 & 0,6 & 20 & 12,8 \\
\hline 1350 & 2 & 190 & 405 & 490,6 & 6 & 12,2 & 385 & 23,8 & 80 & 0,6 & 20 & 12,2 \\
\hline 1450 & 3 & 183 & 409 & 494,6 & 5,9 & 11,9 & 392 & 24,4 & 80 & 0,6 & 20 & 12,1 \\
\hline 1450 & 2 & 107 & 293 & 350,9 & 5,6 & 12,9 & 275 & 25,2 & 80 & 0,6 & 20 & 16,4 \\
\hline 1450 & 3 & 140 & 320 & 380,2 & 6,1 & 12,1 & 335 & 24,9 & 80 & 0,6 & 20 & 12,1 \\
\hline
\end{tabular}

\section{Summary}

In this study has been experienced that titanium alloys with laser welding can be implemented a wide range of applications in the metal industry successfully. Effect of different laser welding power has been investigated on titanium alloy samples' strength. In comparison with $1350 \mathrm{~W}$ and $1450 \mathrm{~W}$ values, it was observed a significant difference at strength values in tensile tests. It has been proved strength trend has dropped after a certain point. For future steps, the effects of welding speed and focus point on joint strength additionally relationship between each other could be investigated.

\section{Acknowledgement}

In this study, I would like to thank BSH Home Appliances Company and my colleagues for their support.

\section{References}

[1.] Aydın, K. \&İ. Karaağaç,Lazer Kaynağı ve Lazer Kaynağının Başlıca Uygulamaları. El-Cezeri Journal of Science and Engineering. 5(2): p. 693-705.

[2.] Özcan, M., N. Tarakçıŏglu, \& Ş. Kahramanlı,Sac malzemelerin lazer kaynak parametreleri. 2004.

[3.] Jokinen, T.,Novel ways of using Nd: YAG laser for welding thick section austenitic stainless steel. 2004: VTT.

[4.] Rykalin, N.N., A. Uglov, \& A. Kokora,Laser machining and welding. 1978: Mir Publishers Moscow.

[5.] Kaluç, E. \&E. Taban,TIG (GTAW) KAYNAK YÖNTEMINDE SON GELIŞMELER VE ENDÜSTRIYYL UYGULAMALARI.

[6.] Fujii, H., K. Takahashi, \& Y. Yamashita, Application of titanium and its alloys for automobile parts. Shinnittetsu giho, 2003: p. 62-67.

[7.] Aydemir, B., E. Aydemir, and E. Kaluç, DP1000 Çelik Sacların Uzaktan Lazer (RLW) ve Direnç Nokta Kaynaklı (RSW) Birleştirmelerinin Çekme ve Yorulma Özeliklerinin İncelenmesi. Mühendis ve Makina, 2017. 58(687): p. 17-28.

[8.] Çağlayan, M.,Alanin-Alanin Sodyum Tuzu Ortamında Ti Bazlı Ti Alaşımlarının Hidroksiapatit İe Kaplanması Ve Kaplamanın Bazı Özelliklerinin İncelenmesi. Fen Bilimleri Enstitüsü, Yüksek Lisans Tezi, Manisa, Türkiye, 2016.

[9.] Pasinli, A., Biyomedikal uygulamalarda kullanılan biyomalzemeler. Makine Teknolojileri Elektronik Dergisi, 2004. 4: p. 25-34.

[10.] Cui, C., et al.,Titanium alloy production technology, market prospects and industry development. Materials \& Design, 2011. 32(3): p. 1684-1691.

[11.] Akman, E., Ti6Al4V titanyum alaşımlarının atımlı Nd: YAG lazeri kullanılarak kaynak edilmesi ve kaynak parametrelerinin belirlenmesi. 2007, Kocaeli Universitesi, Fen Bilimleri Enstitusu.

[12.] Küçükyıldırım, B.O. \& A.A. Eker,KARBON NANOTÜPLER, SENTEZLEME YÖNTEMLERİ VE KULLANIM ALANLARI. Engineer \& the Machinery Magazine, 2012(630).

[13.] Kose, C.\&R. Kacar,Effect of welding speed on the mechanical properties and microstructure of laser welded AISI 316L stainless steel. Journal of the Faculty of Engineering and Architecture of Gazi University, 2015. 30(2): p. 225-235. 
[14.] Uyguntürk, E., et al., Titanyum Boruların Lazer Kaynak Yöntemi ile Birleştirilmesi ve Kaynak Bölgesinin Karakterizasyonu. Politeknik Dergisi.

[15.] Palanco, S., et al.,Spectroscopic diagnostics on $C W$-laser welding plasmas of aluminum alloys. Spectrochimica Acta Part B: Atomic Spectroscopy, 2001. 56(6): p. 651-659.

[16.] Wloka, J., et al.,Corrosion properties of laser beam joints of aluminium with zinc-coated steel. Corrosion science, 2007. 49(11): p. 4243-4258.

[17.] Özden, H.,ENDÜSTRIYEL MAL VE HIZMET ÜRETIMLERINDE PDM, PLM UYGULAMALARI. Mühendis ve Makina, 2016. 57(672): p. 34-43.

[18.] Akkurt, A., A. Şık, \& İ. Ovalı,AA2024 Alüminyum Alaşımlarının Lazer Kaynağında Kaynak Parametrelerinin Mekanik Özelliklere Etkisi. Pamukkale Üniversitesi Mühendislik Bilimleri Dergisi, 2012. 18(1): p. 37-45.

[19.] Kökey, C., et al., INCE PASLANMAZ ÇELIK SACLARIN FIBER LAZER ILE KAYNAK EDILEBILIRLIĞININ INCELENMESI. Mühendis ve Makina, 2016. 57(674): p. 65-72. 